\title{
ESTIMATION OF FREQUENT PEAK FLOOD DISCHARGE FOR THE UPPER RAJANG RIVER BASIN IN SARAWAK, MALAYSIA
}

\author{
JERRY BETIE CHIN ${ }^{1,2}$, KHAMARUZAMAN WAN YUSOF ${ }^{1} \&$ MUBASHER HUSSAIN $^{2}$ \\ ${ }^{1}$ Departmental of Civil and Environmental Engineering, Universiti Teknology Petronas, Malaysia \\ ${ }^{2}$ Hydro Department, Sarawak Energy Berhad, Malaysia
}

\begin{abstract}
Rajang River Basin (RRB) is the largest river basin in Malaysia, in the central region of Sarawak Malaysia. There are two large dams (Murum Dam and Bakun Dam) in upper RRB and these are built as a cascade. Bakun Dam is located downstream of the Murum Dam and to assess the flood risk to the Bakun Dam, the estimation of frequent peak flood discharge (PFD) is important. Rainfall-runoff routing modelling was undertaken with RunOff Routing on Burroughs (RORB) tool to estimate PFD for 1 in 2 annual exceedance probability (AEP) up to 1 in 100 AEP. RORB tool was used to derive flood hydrograph, and a hydrological model was established for the Bakun catchment. Based on the analysis, for the 1-day storm, the 2-year and 100-year return period design rainfall are $115 \mathrm{~mm}$ and $206 \mathrm{~mm}$, respectively. For the 3-day storm, the 2-year and 100-year return period design rainfall are $188 \mathrm{~mm}$ and $344 \mathrm{~mm}$, respectively. The peak flood discharge for 1-day storms is higher than the 3-day storms. For the 1-day storm, the 2-year and 100-year return period, peak flood discharges are $3,867 \mathrm{~m}^{3} / \mathrm{s}$ and $7,043 \mathrm{~m}^{3} / \mathrm{s}$, respectively. For the 3-day storm, the 2-year and 100 -year return period, peak flood discharges are $3,632 \mathrm{~m}^{3} / \mathrm{s}$ and $6,722 \mathrm{~m}^{3} / \mathrm{s}$, respectively.

Keywords: flood risk assessment, Rajang River Basin, peak flood discharge, RORB, flood frequency analysis.
\end{abstract}

\section{INTRODUCTION}

Floods are the most frequently occurring hazard events among all-natural disasters in South East Asia, including the upper Rajang River Basin (RRB) in Sarawak [1]. Flood cause a loss of lives and destruction of properties [2]. RRB is contributing about forty per cent of Sarawak state area, and flood risk assessment for RRB is critical to be assessed for the flood mitigation. RRB is located at the central part of Sarawak; the climate is wet with high rainfall intensity, and because of its topography, it exposes the structures along the Rajang River to the flood risks.

Peak flood discharge (PFD) or design floods are commonly used to assess the potential flood risks. PFD is required for the planning and design of water resources and civil structure projects, flood plain risk management and regulatory compliances. The two commonly used methods for the PFD estimation are streamflow based and rainfall-based [3]. When adequate streamflow data is accessible for a particular site of interest, PFD can be estimated by performing frequency analysis of the recorded inflow data. However, this is not the case for this study, as there is no long-established streamflow station and data. Thus, a rainfall-based flood model will be used, utilising RORB hydrological tool which incorporates the rainfallrunoff routing model.

The RORB tool is commonly used for flood estimation in the Asia Pacific. RORB is an interactive non-linear distributed runoff and streamflow routing program. It calculates catchment losses and streamflow hydrographs from rainfall events input by the user. The hydrology models from RORB were calibrated with the observed stream flows at Bakun Dam. 
Design rainfall storm intensity for the RORB modelling was derived from the rainfall data from six (6) rainfall stations using the rainfall frequency methods. The standard statistical method, Log Pearson Type III, Log-Normal and Gumbel distribution were used to analyse the rainfall frequency.

The key objectives of the study are: (1) to estimate rainfall frequency and intensity; and (2) to estimate the frequent PFD at Bakun Dam.

\section{STUDY AREA AND DATA DESCRIPTION}

\subsection{Study area}

The RRB is the largest river basin in Sarawak, draining an area of approximately $50,000 \mathrm{~km}^{2}$ [1]. The uppermost part of the Rajang River Basin (RRB) which feed into Bakun Dam comprises of four river tributaries, namely Balui River, Bahau River, Linau River and Murum River. Murum River is regulating by the Murum Dam, and the other three river tributaries are freely flowing into Bakun Dam. Fig. 1 shows the overall RRB in Sarawak and Fig. 2 shows the Bakun catchment.

\subsection{Rainfall data}

Historical daily precipitation for six rainfall stations in Bakun catchment was obtained from the Department of Irrigation and Drainage (DID) [4], Sarawak for the period of 1976-2019, as shown in Fig. 2.

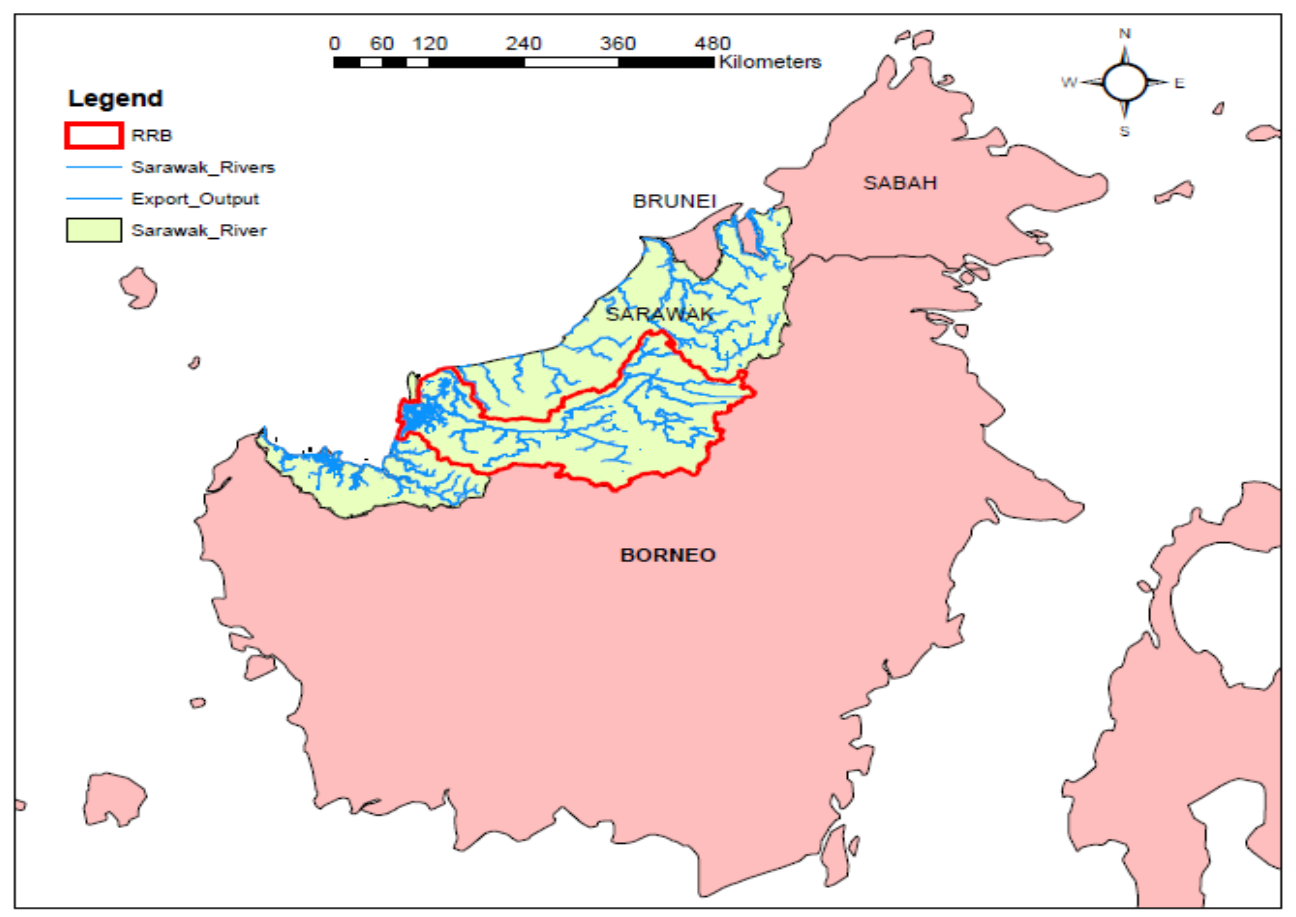

Figure 1: Rajang River Basin in Borneo. 


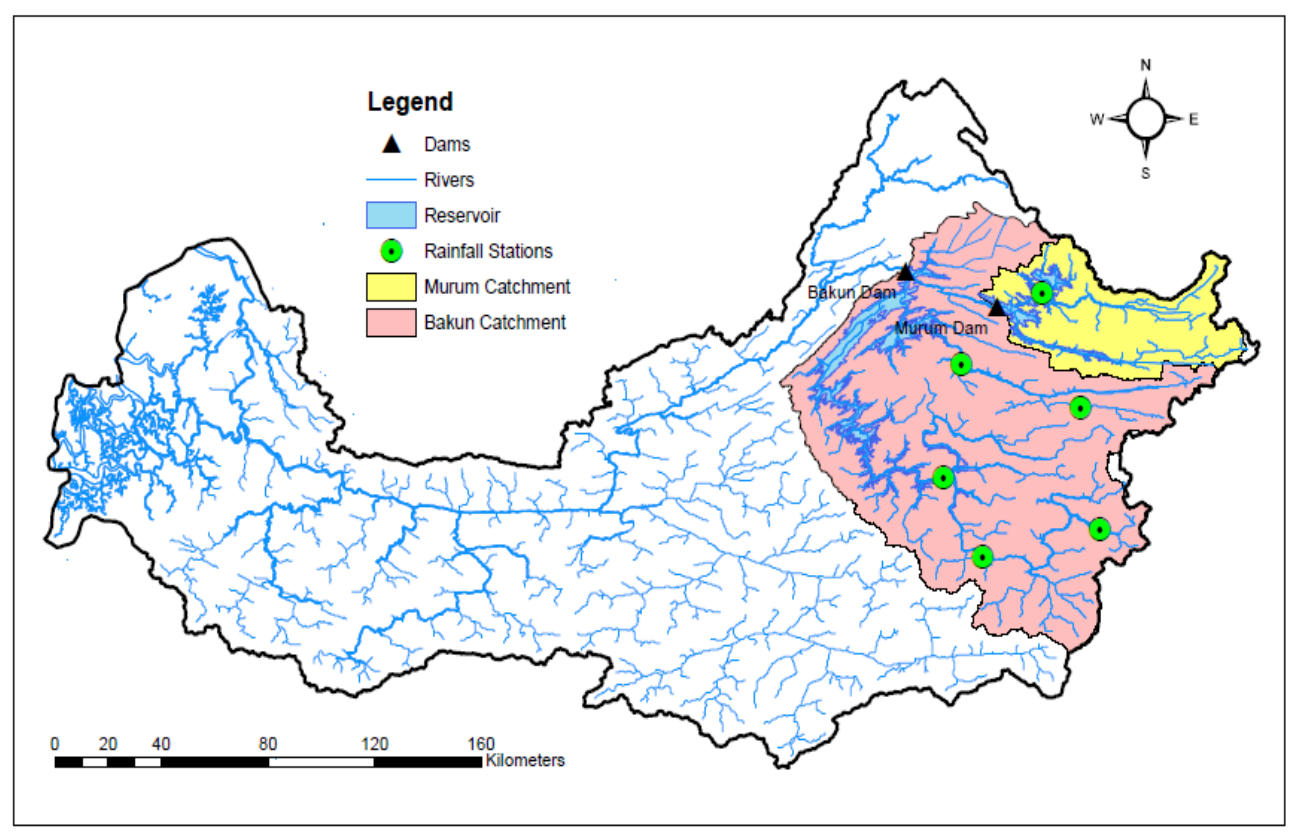

Figure 2: Murum and Bakun catchment with six (6) rainfall stations.

\subsection{Water level and inflow data}

Sarawak Energy Berhad (SEB) has hydrometric stations at Murum Dam and Bakun Dam which records water level and inflow in Murum and Bakun catchments. Water level and inflow at both dams are being archived in the hydrological database through the telemetry system. Inflow data has been scrutinised to establish its suitability for calibration and validation of the continuous hydrological model in RORB.

\subsection{Topographic data}

The topographic data for the catchment and river reaches were obtained from Hydro Department of Sarawak Energy for the two sources as below:

- $\quad$ Light Detection and Ranging (LiDAR) survey data;

- Interferometric Synthetic Aperture Radar (IFSAR).

\section{METHODOLOGY}

\subsection{RORB model development}

RORB is an interactive, non-linear distributed runoff and inflow routing model. This software was chosen because of its widely recognised capabilities in flood routing. It is also easier to use and not required many inputs that lead to fewer assumptions made for the development of the hydrological model. It has also been widely used in many catchments studies in the Asia Pacific as well as in Malaysia for flood risk assessment. RORB is free software and can be downloaded from the internet. 


\subsubsection{Hydrological modelling}

RORB software will be used to perform rainfall-runoff routing modelling to estimate frequent peak flood discharges for 2-year, 5-year, 10-year, 50-year and 100-year return periods.

A RORB model established for the overall Murum and Bakun catchment [5] to estimate frequent peak flood discharge at Bakun Dam. Design rainfalls for the RORB modelling were obtained from the rainfall frequency analysis as described in Section 3.2.1.

\subsubsection{Catchment delineation and reaches and nodes}

RORB model setup begins with the catchment modelling. The catchment was divided into 114 sub-catchments, river links and nodes were connected utilising a combination of LiDAR and IFSAR survey data of the study area. The formed series of link and nodes represent the reaches of flow and the nodes of each sub-catchment, as shown in Fig. 3. Parameters like river length and sub-catchment area were defined and determined.

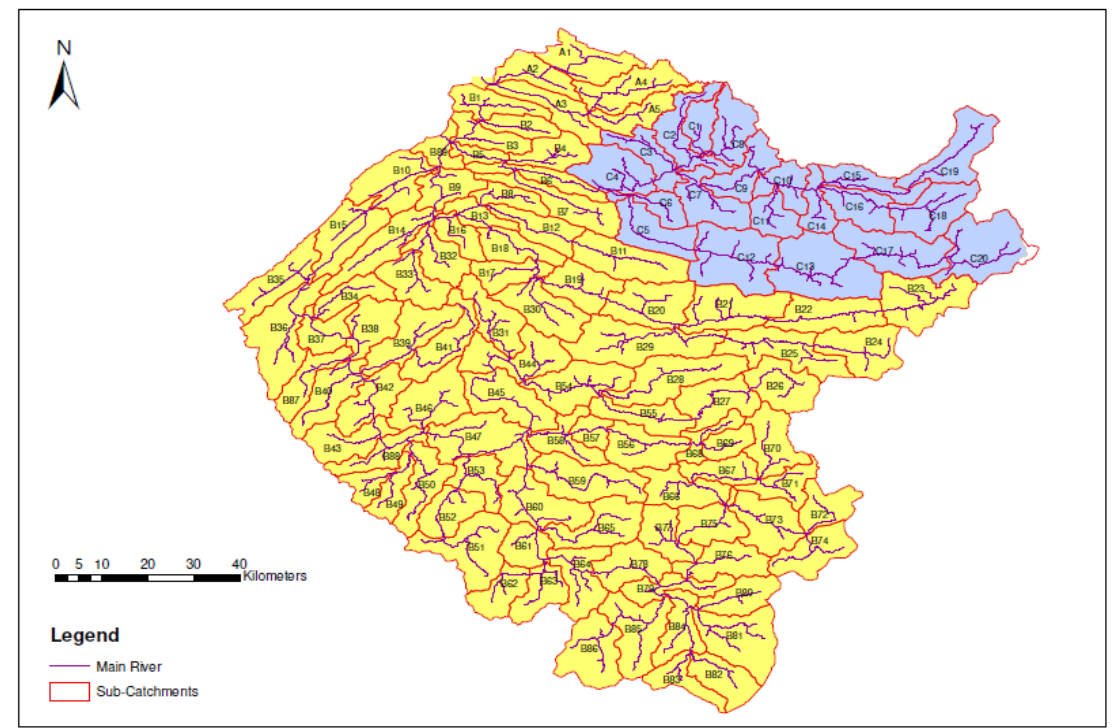

Figure 3: RORB model layout.

The storage discharge relationship in RORB model is:

$$
\mathrm{S}=3600 * \mathrm{~K}_{\mathrm{c}} * \mathrm{~K}_{\mathrm{ri}} * \mathrm{Q}^{\mathrm{m}},
$$

where $\mathrm{S}=$ storage in reach $\left(\mathrm{m}^{3}\right), \mathrm{Q}=$ discharge $\left(\mathrm{m}^{3} / \mathrm{s}\right), \mathrm{Kc}$ and $\mathrm{m}$ are main catchment parameters that can be obtained through trial and error fitting, known as a fit run in RORB model setup, while $\mathrm{K}_{\mathrm{ri}}=$ relative routing lag parameter for the specific reach and storage [5].

\subsection{3 $\mathrm{K}_{\mathrm{c}}$ and $\mathrm{m}$ values in $\mathrm{RORB}$}

In the RORB model, catchment lag and non-linearity are controlled by the factors $\mathrm{K}_{\mathrm{c}}$ and $\mathrm{m}$, respectively. The selection of $\mathrm{K}_{\mathrm{c}}$ and $\mathrm{m}$ values were performed through the fit run. Wide range of peak discharges of the recorded inflow was selected to estimate the $\mathrm{K}_{\mathrm{c}}$ and $\mathrm{m}$ values. Trial and error methods were performed with adjusting range of $\mathrm{K}_{\mathrm{c}}$ and $\mathrm{m}$ values to obtain 
the best fit of the recorded inflow hydrograph. The selected pair of $\mathrm{K}_{\mathrm{c}}$ and $\mathrm{m}$ values were tested against other peak discharge graphs and provided acceptable fit with accuracies within $+/-15 \%$ [6], which is considered as good accuracy. Among all the fit runs, the $m$ value of $0.75, \mathrm{~K}_{\mathrm{c}}$ value of 178 and 0 initial loss (IL) were adopted as the best fit for all the storm events in the study area as shown in Fig. 4.

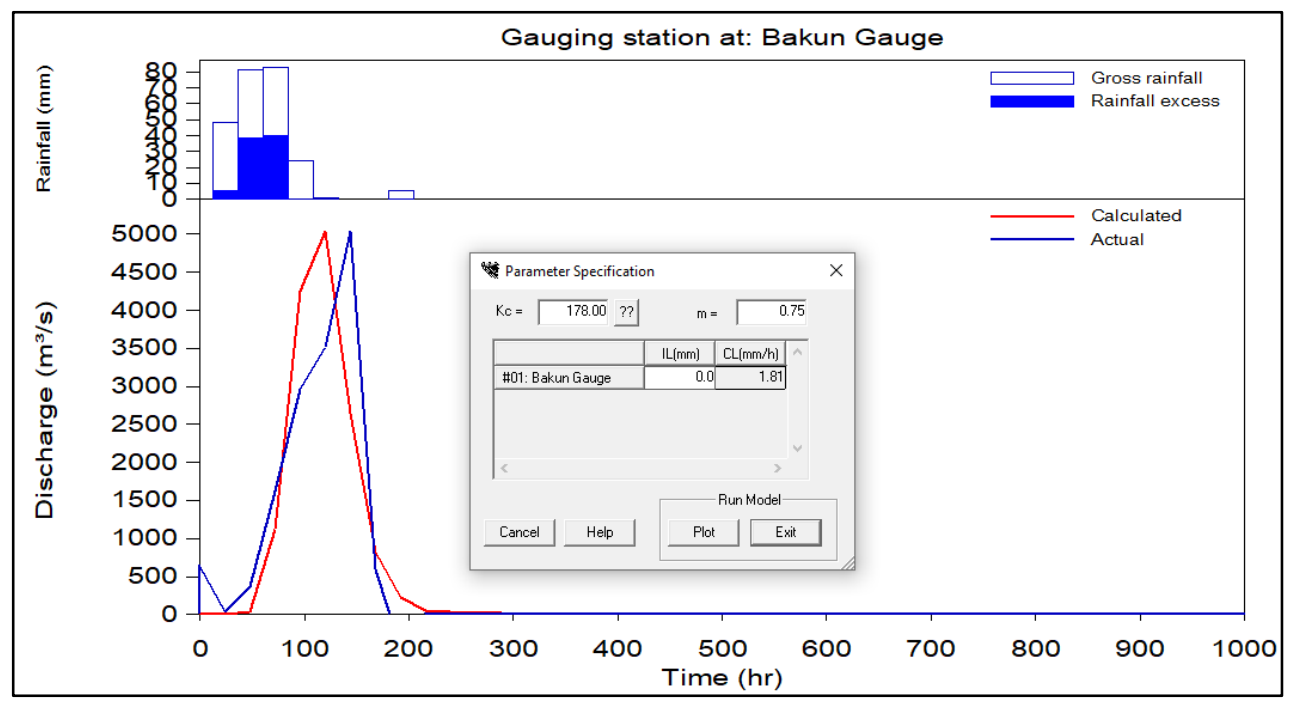

Figure 4: RORB fitted hydrograph using $\mathrm{K}_{\mathrm{c}}=178$.

\subsection{Design rainfall estimate}

\subsubsection{Rainfall frequency analysis}

For this study, three frequency distributions Log Pearson Type III, Log-Normal, and Gumbel were adopted and compared for their ability to fit maximum rainfall values in Murum-Bakun catchment using eqns (2)-(5). Analyses were performed for storm periods of 1-day and 3-day. Daily rainfall data from six stations for the 44-year period (1976-2019) provided the basic data for the study.

In Log Pearson Type III, the coefficient of skewness is calculated using eqn (2) as given below:

$$
C_{\mathrm{s}}=\left(\frac{1}{\sigma^{3}}\right)\left\{\frac{N}{(N-1)(N-2)}\right\} \sum\left(X_{i}-X_{\text {avg }}\right)^{3} .
$$

The frequency factor $\mathrm{k}$ is obtained from the available theoretical table for the Pearson type III distribution.

A Log-Normal distribution is a probability distribution of a random variable whose logarithm is normally distributed. The maximum rainfall for a specific return period is calculated using eqns (3) and (4) [7]

$$
\mathrm{X}_{\mathrm{T}}+\mathrm{X}_{\mathrm{av}}=\mathrm{k} \sigma,
$$

where $\mathrm{X}_{\mathrm{av}}$ is the mean values, $\mathrm{k}$ is the frequency factor and, 


$$
\sigma=\left[\frac{\sum\left(X_{i}-X_{\mathrm{avg}}\right)^{2}}{N-1}\right]^{\frac{1}{2}},
$$

where $\sigma$ is the standard deviation and $\mathrm{N}$ is the sample size. The $\mathrm{k}$ value is estimated with the coefficient of skewness assumes as zero [7].

Gumbel likelihood dissemination is broadly utilised for extraordinary worth examination of hydrologic and meteorological information, for example, floods, most extreme rainfalls and different occasions. The Gumbel formula used for the analysis is given in eqn (5):

$$
X_{T}=X_{\mathrm{av}}-\left(\frac{\sqrt{6}}{\pi}\right) \sigma\left[0.57721+\ln \left\{\ln \frac{T}{T-1}\right\}\right] .
$$

The above empirical relation holds great when the record length is 100 years or more [7].

\subsubsection{Areal reduction and temporal pattern}

Areal reduction factors (ARF's) and temporal pattern have not been published for storm event in Sarawak. Areal adjustments need to be made to the above point rainfalls to convert them to average catchment rainfall estimates. Because of the limited study on storm rainfall variation within Sarawak, ARF values based on a technical report by the US Weather Bureau (USWB) for application with the derived point rainfall estimates are adopted [8]. The ARF is available for various storm durations up to 72 hours and catchment area up to $1000 \mathrm{~km}^{2}$. ARF was extrapolated for a longer duration and larger catchment to adopt in this study.

\section{RESULT AND DISCUSSION}

\subsection{Rainfall frequency analysis}

Design rainfall for various return period is estimated through rainfall frequency analysis using the 44 years historical rainfall record of the river basin. Rainfall frequency analysis was conducted using the Log Pearson Type III, Log-Normal and Gumbel method and the design rainfall for 2 to 100 -year return period are adopted based on the highest value among the three methods. Table 1 shows the peak rainfall for 1-day and 3-day storm event for the 2-year, 5-year, 10-year, 50-year and 100-year return periods. Based on the analysis, for the 1-day storm, the 2-year and 100-year return period design rainfall are $115 \mathrm{~mm}$ and $206 \mathrm{~mm}$, respectively. For the 3-day storm, the 2-year and 100-year return period design rainfall are $188 \mathrm{~mm}$ and $344 \mathrm{~mm}$, respectively.

Table 1: Design rainfall for 1-day and 3-day storm.

\begin{tabular}{|c|c|c|}
\hline $\begin{array}{c}\text { Return period } \\
\text { (year) }\end{array}$ & $\begin{array}{c}\text { 1-day rainfall } \\
\text { (mm) }\end{array}$ & $\begin{array}{c}\text { 3-day rainfall } \\
\text { (mm) }\end{array}$ \\
\hline $\mathbf{2}$ & 115 & 188 \\
\hline $\mathbf{5}$ & 138 & 228 \\
\hline $\mathbf{1 0}$ & 155 & 256 \\
\hline $\mathbf{5 0}$ & 191 & 318 \\
\hline $\mathbf{1 0 0}$ & 206 & 344 \\
\hline
\end{tabular}




\subsection{Frequent peak flood analysis}

After assessing the design rainfall for 2-year to 100-year return period, the design rainfalls were simulated through the RORB hydrological model to generate the peak flood discharge again each design rainfall.

Table 2 shows the peak flood discharge for 1-day and 3-day storm event for the 2-year, 5 -year, 10-year, 50-year and 100-year return periods. Based on the analysis, the peak flood discharge for 1-days storms is higher than the 3-day storms. For the 1-day storm, the 2-year and 100-year return period peak, flood discharges are $3,867 \mathrm{~m}^{3} / \mathrm{s}$ and $7,043 \mathrm{~m}^{3} / \mathrm{s}$, respectively. For the 3-day storm, the 2-year and 100-year return period peak, flood discharges are $3,632 \mathrm{~m}^{3} / \mathrm{s}$ and $6,722 \mathrm{~m}^{3} / \mathrm{s}$, respectively.

Table 2: Summary of the peak flood discharge for the various return period.

\begin{tabular}{|c|c|c|}
\hline \multirow{2}{*}{$\begin{array}{c}\text { Return period } \\
\text { (year) }\end{array}$} & 1-day storm & 3-day storm \\
\hline & $\begin{array}{c}\text { Peak flood discharge } \\
\left(\mathrm{m}^{3} / \mathbf{s}\right)\end{array}$ & $\begin{array}{c}\text { Peak flood discharge } \\
\left(\mathrm{m}^{3} / \mathbf{s}\right)\end{array}$ \\
\hline 2 & 3,867 & 3,632 \\
\hline 5 & 4,687 & 4,425 \\
\hline 10 & 5,259 & 4,979 \\
\hline 50 & 6,516 & 6,207 \\
\hline 100 & 7,043 & 6,722 \\
\hline
\end{tabular}

The values for 1-day and 3-day have been compared and assessed in terms of their variability; even the 1-day peak flood discharges values are higher than the 3-day peak flood discharges, both 1-day and 3-day peak flood discharges will be adopted to assess the flood risk assessment in Upper RRB.

\section{CONCLUSIONS AND RECOMMENDATION}

Based on the results of this study, it is noted that the peak flood discharge for 1-day storm events is higher than 3-day storm events. It would be interesting to assess the flood risk assessment under the 1-day, and 3-day peak flood discharges to assess the flood impact downstream of the Bakun Dam.

It is recommended to extend the analysis to derive the probable maximum precipitation (PMP) and probable maximum flood (PMF) to assess the flood impact under the extreme case.

\section{ACKNOWLEDGEMENTS}

This study is funded by Sarawak Energy Berhad, Malaysia (SEB) under a Master's research program. The authors would like to thanks to SEB for the approval of a research grant and to allow using the data for hydro dams for this study. The authors also thankful to the Department of Irrigation and Drainage, Sarawak for providing the relevant rainfall data for the Rajang River Basin.

\section{REFERENCES}

[1] Hussain, M., Yusof, K.W., Mustafa, M.R.U., Mahmood, R. \& Jia, S., Evaluation of CMIP5 models for projection of future precipitation change in Bornean tropical rainforests. Theoretical and Applied Climatology, 2017. 
[2] Kourgialas, N. \& Karatzas, G., Flood management and a GIS modelling method to assess flood-hazard areas-a case study. Hydrological Sciences Journal, 56(2), pp. 212225, 2011.

[3] Melanie, L., Rahman, A. \& Hagare, D., An Investigation into Design Inputs for Design Flood Estimation in New South Wales, 2012.

[4] DID, Sarawak Hydrological Year Book 2010, Department of Irrigation and Drainage, Sarawak, 2016.

[5] BM Alliance Coal Operations Pty Ltd., Flood hydrology technical report, Red Hill Mining Lease EIS, 2013.

[6] Laurenson, R.G.M.E.M. \& Nathan, R.J., RORB Version 6: Runoff Routing Program User Manual, Monash University and Hydrology and Risk Consulting Pty Ltd, Jan. 2010.

[7] Sabarish, R.M., Narasimhan, R., Chandhru, A.R., Suribabu, C.R., Sudharsan, J. \& Nithiyanantham, S., Probability analysis for consecutive-day maximum rainfall for Tiruchirapalli City (south India, Asia). Applied Water Science, 7, pp. 1033-1042, 2017.

[8] SMEC, Baleh hydroelectric project: Hydrology review and update, Sarawak Energy Berhad, Jul. 2013. 